\title{
Sustainable Earnings and Its Forecast: The Case of Vietnam*
}

\author{
Nhung Hong DO ${ }^{* *}$, Nha Van Tue PHAM${ }^{* * * *}$, Dung Manh TRAN**** , Thuy Thu LE ${ }^{* * * * *}$
}

Received: December 19, 2019 Revised: February 02, 2020 Accepted: February 06, 2020.

\begin{abstract}
The study aims to provide better understanding of sustainable earnings by a comprehensive analysis of earnings persistence of business firms in Vietnam as an example of developing economies in South-East Asia. Dataset of 1,278 publicly listed firms (excluding banking and financial services firms) on Vietnam Stock Exchange for the period from 2008 to 2017 was collected. By applying fixed effect regression model, the empirical results provided the basis to measure the persistence index (Pers index) and find low level of their earnings persistence. The literature of earnings quality analysis in developed countries suggests earnings persistence as a noteworthy determinant of future earnings forecast and stock valuation. However, research of sustainable earnings in developing countries is still highly underdeveloped. For Vietnamese listed firms, the average Pers index was estimated for the period from 2008 to 2010, indicating low level of earnings persistence. We also incorporated earnings persistence level into future earnings forecast by running the quintile regression model divided the data into four equal levels and conducted each section independently to see the difference in each percentile, thence assessed the factors' influence on the specific model. The findings provide important information on the expected returns of firms, especially helping investors make sound decisions.
\end{abstract}

Keywords: Sustainable Earnings, Earnings Persistence, Earnings Volatility, Vietnam.

JEL Classification Code: G32, G30, M410

\section{Introduction}

Earnings persistence has been addressed in the literature of profit forecasting, which provides the basis for security valuation and business enterprise valuation. Investors wish to determine the fair price of stocks and thus identify the

*We would like to thank National Economics University of Vietnam. Also thank Tuan Vu Dang, Thanh Huyen Nguyen, Dinh Hoat Dang, Anh Nguyet Tran and FiinGroup for providing access to the Database. We also acknowledge this research is funded by National Economics University, Hanoi, Vietnam

${ }^{* \star}$ First Author and Corresponding Author. Lecturer, National Economics University, Vietnam [Postal Address: 207 Giai Phong Road, Hai Ba Trung District, Hanoi, 100000, Vietnam]

Email: nhungdh@gmail.com

***Lecturer, National Economics University, Vietnam. Email: vantuenha@gmail.com

${ }^{* * * \star}$ Associate Professor, National Economics University, Vietnam. Email: manhdung@ktpt.edu.vn

*****Lecturer, National Economics University, Vietnam. Email: lethuthuyktqd@gmail.com

(c) Copyright: The Author(s)

This is an Open Access article distributed under the terms of the Creative Commons Attribution NonCommercial License (https://creativecommons.org/licenses/by-nc/4.0/) which permits unrestricted noncommercial use, distribution, and reproduction in any medium, provided the original work is properly cited. overpriced and underpriced stocks. They will subsequently select the underpriced stocks as investment targets. Therefore, the key question for every investor is how to determine stocks' fair prices. Basically, the fair price of a stock can be computed by applying various discounted earnings models, most of which require firm' future earnings prediction. Although the forecasting methods may vary, every prediction of future earnings starts with a review of current earnings. For a long time, it was believed that firms' earnings did not strictly follow "random walk" pattern, instead past earnings and future earnings are somehow correlated (Graham \& Dodd, 1951; Ball \& Watts, 1972). The likelihood of current earnings to be sustained in future is referred to as earnings persistence. Ceteris paribus, future earnings tend to be more assured when earnings are more persistent. Therefore, estimating earnings persistence and incorporating it should be an essential part of developing earnings prediction models.

Another approach towards earnings forecast based on sustainable earnings analysis was proposed by Frankel and Litov (2009) as they examined earnings predictability differences of firms with different levels of past earnings volatility. Their findings show that past earnings volatility negatively affected current earnings persistence, thus it 
could be used to predict future earnings. Frankel and Litov (2009) also confirmed the importance of sustainable earnings forecast for business enterprise valuation. Similarly, Moienadin and Tabatabaenasab (2014) proved the relationship between current and future earnings as well as the relationship between sustainable earnings and cash dividend ratio.

Previous studies in developed countries identified various influential factors of earnings persistence such as business cycles (Johnson, 1999); profit margin level (Amir, Einhorn, \& Kama, 2012). However, the influences of operating cash flow, accruals and profit margin changes on earnings persistence have not been analyzed in depth. In Vietnam, studies of sustainable earnings are also very limited as they mainly relied on the analyses of past profit growth rates and business environment to predict short-term future earnings, which involved subjective and intuitive assessment of the analysts. Besides, a few studies developed long-term earnings forecast models based on earnings' influential determinants of firms in certain industries but the impact of each factor was not analyzed in detail.

For stock markets in developing countries, questionable accounting and financial information quality of business firms are still a potential trouble for investors, which calls for more advanced research. For instance, a number of Vietnamese listed firms were reported to have highly volatile earnings over time or even experience financial distress and bankruptcy due to unsustainable business operations and low predictability of future earnings, which gave way to security market shocks and investors' losses. In such a situation, investors are supposed to improve their perception of earnings persistence and its importance for future profitability forecasting and investment decision making. Nonetheless, research on earnings persistence in developing countries is apparently not so well-established as earnings persistence is sparsely and incomprehensively estimated and integrated into forecasting models of their business firms. Besides, there was no widely publicized research of influential determinants of sustainable earnings in those countries either. As a result, our study was conducted as an attempt to cope with such research gap. As we focused on identifying the impacting determinants of earnings persistence of publicly traded firms in Vietnam and subsequently examining the effect of earnings persistence on earnings forecast of those firms, we hope to contribute to the literature of sustainable earnings analysis in developing economies where a lot of investors are in need of a theoretically supported and practically applicable guidance for stock valuation and investment decision making.

In general, despite the underdeveloped literature of sustainable earnings in Vietnam, it is undeniably necessary to develop long-term sustainable earnings forecast model as firms' managers and investors can benefit from it in their decision sound making (Nguyen \& Nguyen, 2020). Therefore, we conduct this research to firstly identify the influential determinants of sustainable earnings, develop a proxy to measure firms' earnings persistence level, which will then be employed for future earnings forecast of business firms in Vietnam.

\section{Literature Review and Hypotheses}

Earnings persistence has its roots from works of profit and stock return forecast. In general, the ability of current earnings to be sustained in future is termed earnings persistence. To estimate earnings persistence, the following lag regression model was employed in early relevant works (Komendi \& Lipe, 1987; Penman \& Zhang, 2004; Lev \& Thiagarajan, 1993; Sloan, 1996):

$$
\mathrm{E}_{\mathrm{t}}=\alpha_{0}+\alpha_{1} \mathrm{E}_{\mathrm{t}-1}+\varepsilon_{\mathrm{t}}
$$

where $E_{t}$ and $E_{t-1}$ are respectively earnings of the current and previous periods. Firm's earnings of different periods are correlated if the slope coefficient $\alpha_{1}$ is statistically significantly different from zero. $\alpha_{1}$ closer to 1 indicates higher earnings persistence while $\alpha_{1}$ being statistically insignificant or very close to 0 indicates random walk pattern of earnings over time. Till now, such approach is still the most commonly applied in the literature of earnings persistence estimation even though the measurement of earnings variable may differ depending on researchers' perspectives (Abarbanell \& Bushee, 1997; Chan, Lakonishok, \& Sougiannis, 2001; Fairfield \& Yohn, 2001; Sloan, 1996; Fairfield \& Yohn, 2001). Moreover, Penman and Zhang (2004) extended the conceptual discussion of earnings persistence as they attributed the sustainable component of additional earnings to investment in net operating assets while earnings improvement due to change of return on assets is transitory or unsustainable.

Such conceptualization of earnings persistence/sustainable earnings has great contribution to the practice of asset valuation as it provides investors with a theoretical framework of forecasting future earnings which will subsequently be discounted to determine present value of the investment (Brownlee, Ferris, \& Haskins, 1990; Haskins, Ferris, Sack, \& Allen, 1993; Kieso \& Weygandt, 1995; Damodaran, 1999). Hence the practice of earnings prediction and asset valuation can benefit from improving earnings persistence and earnings quality (Dechow \& Schrand, 2004; Richardson, Sloan, Soliman, \& Tunaa, 2005). 


\subsection{Determinants of Earnings Persistence}

Previous studies identify a number of potentially impacting determinants of earnings persistence, which can be categorized into 3 groups, i.e. (Firm-specific) financial performance determinants, (firm-specific) accounting methodology determinants and industry characteristic determinants (Muhammad \& Wagas, 2016).

\subsubsection{Financial Performance Determinants}

Earnings volatility is arguably the most studied factor. There are both theoretical arguments and empirical evidences for negative relationship between volatility level and earnings persistence although volatility level measurement may vary (Brooks \& Buckmaster, 1976; Freeman \& Tse, 1989; Das \& Lev, 1994; Beaver \& Kettler, 1970; Dichev \& Tang, 2009; Frankel \& Litov, 2009). Such negative impact can be explained as the result of competition pressures in the market of investment assets, which makes extraordinary earnings unsustainable (Beaver $\&$ Kettler, 1970). Chen (2004) took a further step as he not only examined earnings persistence effect of earnings volatility level but also that of forces behind earnings volatility, which are represented by the correlation between earnings volatility and profit margin changes as well as asset turnover changes. However, such novel approach has not been adapted much in later studies.

Asset growth may contribute to earnings persistence as well. As Penman and Zhang (2004) suggested, earnings increases are sustainable only if they are the result of additional investment in net operating assets. Chen (2004), Li (2005), and Kocamis and Gungor (2016) integrated asset growth into their earnings persistence model accordingly as an independent variable which is proven to have significantly positive sign.

In addition, capital structure also has well-developed theoretical framework for its effect on future earnings (Dao \& Lai, 2018). Nonetheless, studies of capital structure's influence on earnings persistence are limited with unclear or non-unanimous conclusion. In the empirical research by Al-Momani (2017), three different capital structure ratios were employed but only one of them was proven to have statistically significant and positive effect on earnings persistence. Hogan (2013) also found capital structure to have significant effect on earnings persistence of a certain group of firms (not all firms in the sample) but such effect turned out to be negative.

\subsubsection{Accounting Approach Determinants}

Previous works found that the accounting of losses can impact earnings persistence as some firms may recognize expected loss transactions in current period (Basu, 1997). Accounting conservatism also requires firms to recognize losses due to temporarily negative shocks on a timely basis while positive shocks' effects are only gradually recognized over several periods, making losses less long-lasting than profit. Therefore, losses are generally less persistent than profit in practice (Narayanamoorthy, 2006).

Accounting methodology may also exert its influence on sustainable earnings via the formation of accruals. Empirical studies by Dichev and Tang (2004), Frankel and Litov (2009), and Barth and Hutton (2004) confirmed negative impact of accruals' amount on earnings persistence as there are potentially more subjectivity and mistakes by accountants in the accounting of accruals in comparison with cash flow accounting (Sloan, 1996; Xie, 2001; Ball, Gerakos, Linnainmaa, \& Nikolavea, 2016). Darjezi (2016); and Dechow and Ross (2005) took further step to investigate earnings persistence effect of accruals' certain aspects such as accruals' quality and their duration.

In contrary to accruals, the cash flow component of earnings was proven to positively influence earnings persistence (Dechow et al., 2008; Dang \& Tran, 2019). Basically, accruals and cash flows can be regarded as the two integral components of earnings so when the cash flow component's weight increases, the weight of accruals must decrease (and vice versa) and they have opposite effects on earnings persistence. However, cash flow component is similar to accruals in the sense that not only their amount but also their quality can affect earnings persistence (Dichev \& Tang, 2009).

\subsubsection{Industry Characteristic Determinants}

The structure of market share of an industry may affect sustainable of firms in such industry. According to Dechow et al. (2009), a firm's market share indicates its position in the industry and has positive impact on its earnings quality. Previous work by Chen (2004) also empirically proved positive correlation between firm's market share and its earnings persistence. Market share structure also implies market concentration. The fact that most of the market shares are acquired by a small number of firms signals high level of market concentration and those firms are more capable of sustaining their earnings thanks to their oligopolistic power. A few researchers hence attempted to empirically test earnings persistence effect of market concentration (Chen, 2004; Hogan, 2013) but most of them ended up with a statistically insignificant result.

Besides, capital intensity may represent industry's barriers to entry so intuitively higher capital intensity should result in more sustainable earnings for existing firms of the industry (Lev, 1983; Gregory, Whittaker, \& Yan, 2016). Nevertheless, the impact of capital intensity on earnings persistence is not widely examined in empirical studies yet.

In Vietnam, research on influential determinants of 
earnings persistence is still very limited. The only notable paper was publicized by Nguyen, Nguyen, and Nguyen (2014), who studied the impact of accruals accounting on sustainable earnings, but their earnings persistence model did not fully incorporate all the potential impacting determinants as suggested in the literature. There are a few studies about influential determinants of earnings quality (Duong, 2013; Bui \& Nguyen, 2018) but none of them explicitly integrated earnings persistence as the dependent variable in their research models. The lack of a comprehensive study of influential determinants of earnings persistence hence implies a considerable research gap in Vietnam as well as other developing countries.

As a result, our study makes a comprehensive effort in examining the influential determinants of earnings persistence in Vietnam by testing the hypothesis that earnings persistence of Vietnamese listed firms is influenced by all three groups of determinants: Financial performance determinants, accounting methodology determinants and industry characteristic determinants (Hypothesis 1). In particular, to investigate the potential impact of earnings volatility, the approach by Chen (2004) was adapted to analyze the relationships between earnings volatility's driving forces and earnings persistence in depth. Besides, as profitability is proxied by return on operating assets instead of net income, the potential effect of financial leverage is removed and thus not needed to be integrated into the model.

\subsection{Earnings Persistence and Earnings Forecast}

Although earnings persistence has been empirically widely proven to affect future financial performance, works of earnings forecast are largely yet to implicitly employ earnings persistence as the basis for earnings forecast. For instance, a wide range of typical studies (e.g., Jackson, Plumlee, \& Rountree, 2018; Fairfield \& Yohn, 2001; Schröder \& Yim, 2016) applied various mathematical and statistical methods such as time series regression, earnings disaggregation using DuPont equation or financial and nonfinancial factor regression analysis to forecast earnings but did not emphasize the allegedly important role of earnings persistence in earnings forecast. Those studies actually intended to examine the efficiency of different forecasting methods and forecasting models in which earnings persistence was not regarded as a variable of interest or even non-existent.

Meanwhile, there is just a highly limited number of earnings forecast studies relying on earnings persistence analysis with certain drawbacks. In particular, the research by Penman and Zhang (2004) made an effort to correlate earnings persistence's influential determinants with future earnings volatility but such attempt served only as an intermediate step to achieve their ultimate research objective which is to explain the fluctuations of $\mathrm{P} / \mathrm{E}$ rather than to predict future profit. Dichev and Tang (2009), and Frankle and Litov (2008) also studied the impact of earnings volatility on earnings predictability by comparing earnings predictability across groups of firms with different earnings volatility without constructing an implicit earnings persistence-based forecasting model. Other studies mostly based on analysis of past profitability and allegedly influential determinants of sustainable earnings as cash flows and accruals to make predictions of future profitability (Richardson et al., 2005; Fairfield \& Yohn, 2001). Chen (2004) was the only one to create a proxy which comprehensively represented earnings persistence and incorporated it into his future earnings forecasting model. The proxy can be calculated based on regression coefficients and values of independent variables of earnings persistence's impacting determinants analysis model. The proxy was empirically proven to be statistically significant too. Nevertheless, that research by Chen (2004) was the only one to achieve such feat.

In Vietnam, studies of financial performance forecast are not widely publicized and those applying earnings persistence to forecast future earnings are extremely rare. Those studies apparently have underdeveloped content and methodology as their results are not yet internationally recognized. For example, Nguyen et al. (2014) found cash flow component of earnings to have higher persistence level than accruals and positive effect on earnings forecast accuracy but did not develop earnings forecast model implicitly based on earnings persistence. A few other studies developed earnings or cash flow forecast models but did not integrate earnings persistence into the model, with their results presented only in working papers or internally circulated research reports of some domestic educational institutions so the research quality was still unconfirmed. In short, earnings persistence is yet to be comprehensively and thoroughly applied as the basis of works on future earnings forecast in Vietnam.

In short, the problem of forecasting earnings based on earnings persistence analysis is still not fully resolved even in developed countries. In Vietnam as well as other developing countries, there is even a bigger gap in the literature of sustainable earnings analysis and earnings prediction which needs to be addressed and filled. Therefore, our research is conducted to develop a profitability forecasting model based on earnings persistence analysis of Vietnamese listed firms. Following previous studies especially the research by Chen (2004), we hypothesize that earnings persistence level of Vietnamese listed firms can be determined by analyzing sustainable earnings' influential determinants (Hypothesis 2). Another proposed hypothesis is that future profitability of those 
firms can be forecasted based on their sustainable earnings analysis (Hypothesis 3). Profitability forecasting method and forecast error analysis method are adapted from Dichev and Tang (2009). Our contribution is to expand the literature of examining sustainable earnings' impacting determinants and applying earnings persistence to predict future earnings, which is still highly insufficient in Vietnam and other developing countries.

\section{Research Methodology}

\subsection{Research Models and Variables}

The model is approached to analyze the persistence profit of listed companies on the Vietnamese stock market by offering determinants that affect sustainable profitability and assess its impact on the sustainable of corporate profits. From the identification of influencing determinants and impact level on sustainable profits, the study provides a method to estimate the sustainability of corporate profits and hypothesize that sustainable profits are one of determinants which help predict the profitability of businesses in the future. Based on the literature review, the determinants affecting sustainable profitability of firms are categorized into 3 main groups as follows:

Firstly, the group of influential determinants representing industry characteristics (see Table 1):

Table 1: Industry characteristics -based independent variables

\begin{tabular}{|l|c|c|c|l|}
\hline \multicolumn{1}{|c|}{ Variable } & Formula & Notation & Predicted sign & \multicolumn{1}{c|}{ Sources } \\
\hline Market Share & $\begin{array}{c}\text { Corporate income } \\
\text { Industry income }\end{array}$ & MS & $(+)$ & $\begin{array}{l}\text { Dechow et al., (2001, 2006), Nguyen et } \\
\text { al. (2019) }\end{array}$ \\
\hline Herfindahl Index & $\begin{array}{l}\text { HERF }=\text { Sum of squared market shares in the } \\
\text { industry }\end{array}$ & HERF & $(+)$ & $\begin{array}{l}\text { Lev (1983), Chen (2004), Gregory et al. } \\
(2014), \text { Frankel \& Litov (2009). }\end{array}$ \\
\hline Capital Intensity & $\mathrm{CI}=\frac{\text { Depreciation, depletion expenses }}{\text { Sales }}$ & CI & $(+/-)$ & $\begin{array}{l}\text { Lev (1983), Johnson (1999), Gregory et } \\
\text { al. (2016), Frankel \& Litov (2009) }\end{array}$ \\
\hline Firm Size & SIZE $=\ln$ (Assets) & SIZE & $(+)$ & $\begin{array}{l}\text { Lev (1983), Frankel \& Litov (2009), } \\
\text { Chen (2004). }\end{array}$ \\
\hline
\end{tabular}

Table 2: Financial statement fundamentals-based independent variables

\begin{tabular}{|c|c|c|c|c|}
\hline Variables & Formula & Notation & $\begin{array}{l}\text { Predicted } \\
\text { Signs }\end{array}$ & Sources \\
\hline $\begin{array}{l}\text { Profit } \\
\text { Margin } \\
\text { Dummy }\end{array}$ & $\begin{array}{l}=1 \text { if the yearly change of profit margin is in the same direction as the } \\
\text { yearly change in earnings, and } 0 \text { otherwise, where profit margin= } \\
\text { operating income after depreciation/Sales }\end{array}$ & DPM & $(+/-)$ & $\begin{array}{l}\text { Kocamis \& Gungor (2016), } \\
\text { Chen (2004), Penman \& } \\
\text { Zhang (2004), Le \& } \\
\text { Truong (2019) }\end{array}$ \\
\hline $\begin{array}{l}\text { Asset } \\
\text { Turnover } \\
\text { Dummy }\end{array}$ & $\begin{array}{l}=1 \text { if the yearly change of asset turnover is in the same direction as the } \\
\text { yearly change in earnings, and } 0 \text { otherwise, where asset turnover= } \\
\text { Sales/Assets. }\end{array}$ & DATO & $(+/-)$ & $\begin{array}{l}\text { Chen (2004), Li (2005), } \\
\text { Penman \& Zhang (2004) }\end{array}$ \\
\hline $\begin{array}{l}\text { Growth in } \\
\text { Assets }\end{array}$ & $\left(\right.$ Assets $_{t}-$ Assets $\left._{\mathrm{t}-1}\right) /$ Assets $_{\mathrm{t}-1}$ & GA & $(+/-)$ & $\begin{array}{l}\text { Chen (2004), Kocamis \& } \\
\text { Gungor (2016), Li (2005). }\end{array}$ \\
\hline $\begin{array}{l}\text { Interactive } \\
\text { Effect of } \\
\text { PM and } \\
\text { ATO } \\
\text { Dummy }\end{array}$ & $\begin{array}{l}=1 \text { if yearly changes of profit margin and asset turnover are in the } \\
\text { difference direction, and } 0 \text { otherwise. }\end{array}$ & DPMATO & $(-)$ & $\begin{array}{l}\text { Chen (2004), Dechow \& } \\
\text { Schrand (2004). }\end{array}$ \\
\hline $\begin{array}{l}\text { Interactive } \\
\text { Effect of } \\
\text { ATO and } \\
\text { GA } \\
\text { Dummy }\end{array}$ & $\begin{array}{l}=1 \text { if yearly changes of asset turnover and earnings are both positive, } \\
\text { but growth in assets is negative; or if yearly changes of asset turnover } \\
\text { and earnings are both negative, but the growth in assets is positive, and } \\
0 \text { otherwise. }\end{array}$ & DATOGA & $(+)$ & $\begin{array}{l}\text { Chen (2004), Penman \& } \\
\text { Zhang (2004). }\end{array}$ \\
\hline
\end{tabular}

Secondly, the group of influential determinants representing the financial situation and performance of the business (see Table 2).
Thirdly, the group of influential determinants representing the accounting method of the enterprise (see Table 3). 
Table 3: Accounting methodology-based independent variables

\begin{tabular}{|l|l|c|c|c|}
\hline \multicolumn{1}{|c|}{ Variables } & \multicolumn{1}{|c|}{ Descriptions } & Notation & $\begin{array}{c}\text { Predicted } \\
\text { Signs }\end{array}$ & Sources \\
\hline $\begin{array}{l}\text { Absolute } \\
\begin{array}{l}\text { Value } \\
\text { Accruals }\end{array}\end{array}$ & $\begin{array}{l}\text { Absolute value of accruals/Sales, where accruals= } \\
\text { Change in Current assets - Change in cash/cash } \\
\text { equivalents - (Change in current liabilities - Change in } \\
\text { debt included in current liabilities - Change in income } \\
\text { taxes payable - Depreciation and amortization expense }\end{array}$ & ACCR & $(-)$ & $\begin{array}{l}\text { Chen (2004), Narayanamoorthy (2006), } \\
\text { Frankel \& Litov (2009), Rangan \& } \\
\text { Sloan (1998) }\end{array}$ \\
\hline Loss Dummy & $=1$ when Earnings is negative, and 0 otherwise & LOSS & $(-)$ & $\begin{array}{l}\text { Chen (2004), Johnson (1999), } \\
\text { Bhattacharya et al. (2012). }\end{array}$ \\
\hline $\begin{array}{l}\text { Decrease } \\
\text { Dummy }\end{array}$ & $\begin{array}{l}\text { J } 1 \text { when Change in Earnings is negative and zero } \\
\text { otherwise }\end{array}$ & DECR & $\begin{array}{l}\text { Chen (2004), Johnson (1999), } \\
\text { Bhattacharya et al. (2012), Rangan \& } \\
\text { Sloan (1998) }\end{array}$ \\
\hline
\end{tabular}

Firstly, those independent variables are incorporated into the following model (model 1) to estimate the relationship between the aforementioned determinants and the transitory component of standardized annual profit. Model 1:

$$
\begin{aligned}
S U E_{(t-1)}=a_{0}+ & \sum_{n}^{i=1}\left(b_{i} \times F_{(i, t-2)}\right) \\
& +\left(c_{0}+\sum_{n}^{i=1}\left(c_{i} \times F_{(i, t-2)}\right)\right) \times S U E_{(t-2)} \\
& +\varepsilon_{(t-1)}
\end{aligned}
$$

where SUE is the difference of standardized annual profit scaled by total assets; $F_{i}$ are determinants affecting the sustainability of profits which are divided into 3 groups as described above.

Subsequently, the estimation results of model 1's regression coefficients are used to calculate the profit's persistence index, which is denoted as "Pers", as follows:

$\operatorname{Pers}_{t}=c_{0}^{t-1}+\sum_{i=1}^{n} c_{i}^{t-1} \times F_{i, t}$

The "Pers" index is then incorporated into sustainability measurement model which is used to estimate the impact of earnings persistence determinants on future earnings:

$$
\begin{aligned}
\operatorname{SUE}_{\mathrm{t}+\mathrm{k}} & =\mathrm{a}_{\mathrm{k}}+\mathrm{b}_{\mathrm{k}} \times \mathrm{SUE}_{\mathrm{t}}+\varepsilon_{\mathrm{t}+\mathrm{k}} \\
\mathrm{SUE}_{\mathrm{t}+\mathrm{k}} & =\mathrm{a}_{\mathrm{k}}+\mathrm{b}_{\mathrm{k}} \times \mathrm{SUE}_{\mathrm{t}}+\mathrm{c}_{\mathrm{k}} \times \operatorname{Pers}_{\mathrm{t}}+\mathrm{d}_{\mathrm{k}} \times \operatorname{Pers}_{\mathrm{t}} \times \mathrm{SUE}_{\mathrm{t}}+
\end{aligned}
$$

Model 1 is employed as the "major" model of our research as it provides a comprehensive estimation of potential influential determinants of earnings persistence. The discussion section of this paper will concentrate on the estimation results of this model. In addition, we also develop three other models (Models 2, 3 and 4) to investigate the effects of some significant determinants on different aspects of earnings persistence in more detail. These models are described below.

As earnings volatility is one of the most specifically researched and universally recognized influential determinants of profit sustainability in the literature, it makes sense to examine the effect of earnings volatility on future profit in the context of emerging markets which may differ from developed markets (Lau \& Mahat, 2019). We employ an additional model (model 2) for this purpose: Model 2:

Earnings $_{\mathrm{i}, \mathrm{t}+\mathrm{k}}=\alpha+\beta \times$ Earnings $_{\mathrm{i}, \mathrm{t}}+\varepsilon_{\mathrm{i}, \mathrm{t}+\mathrm{k}} \quad \boldsymbol{k}=\mathbf{1} \rightarrow \mathbf{5}$

The earnings variable in the model is earnings before extraordinary item deflated by average total assets. The examination of earnings volatility's effect on future earnings is conducted rather indirectly. Instead of directly incorporating a proxy for earnings volatility into the model, we divide the sample of selected firms into quintiles based on their earnings volatility levels in each year, which is calculated as earnings' standard deviation in the last 5 years. We then run regression model (2) for the first quintile (firms with lowest earnings volatility) and fifth quintile (firms with highest earnings volatility) only. Subsequently, we compare the value of beta coefficients of the two regression models and test the statistical significance of their difference. The purpose of this model is to examine whether difference in earnings volatility actually causes difference in future earnings, particularly for the groups of firms with the most extreme earnings volatility.

Besides, we expand the investigation of earnings volatility's effect on earnings predictability by examining the relationship between earnings volatility and future earnings forecast error. Model (3) is developed for this purpose. Model 3:

$$
F E_{t+1}=b_{1}+b_{2} \times H i g h_{V o l t}+b_{3} \times F E_{t}+b_{4} \times
$$$$
\text { High }_{\text {Volt }} \times F E_{t}+\varepsilon
$$

where High_volt is the dummy variable which is equal to 1 for firms in the highest quintile of earnings volatility and 
0 for firms in the lowest quintile (firms in other quintiles are not considered); FE is the forecast error which is equal to the difference between the actual profit and the median of the forecasted profit before the actual profit is announced. This model helps to examine whether difference in earnings volatility actually causes difference in earnings forecast errors (hence difference in earnings predictability), particularly for firms with the most extreme earnings volatility.

Aside from earnings volatility, accruals are also another common influential determinant of earnings persistence in the literature. Therefore, it is necessary to investigate the influence of accruals on future earnings in more detail by breaking down accruals into components and examine each component's earnings persistence effect. Model 4 is developed for this purpose. Model 4: Testing the role of accruals' components in predicting future profits.

$\mathrm{NI}_{\mathrm{t}+1}=\alpha_{0}+\alpha_{1} \times \mathrm{CACC}_{\mathrm{t}}+\alpha_{2} \times \mathrm{NCACC}_{\mathrm{t}}+\alpha_{3} \times \mathrm{FCF}_{\mathrm{t}}+\mathrm{u}_{\mathrm{t}}$
The variables in model 4 are defined as follows:

CACC: Short-term accrued profit from business activities $=[\Delta$ (Short-term assets - Cash and cash equivalents) $-\Delta$ (Short-term debts - Short-term loans)] / Total average assets

NCACC: Long-term accrued profits from business activities $=[\Delta$ (Total assets - Short-term assets $)-\Delta$ (Total debts - Short-term liabilities - Long-term borrowings) / Total average assets

FCF: Free cash flow / Total average assets

\subsection{Sample Selection}

The dataset of 1,278 businesses collected as of December 2018 is divided into 9 sectors by Industry Classification Benchmark. In this study, firms in finance, banking and insurance sectors are excluded. This exclusion is appropriate because businesses in these sectors are very different from the rest of the businesses, businesses have historical data less than 4 years are also excluded (Table 4 ).

Table 4: Number of firms in sectors from 2007 to 2017

\begin{tabular}{|c|c|c|c|c|c|c|c|c|c|c|c|}
\hline Sectors & 2007 & 2008 & 2009 & 2010 & 2011 & 2012 & 2013 & 2014 & 2015 & 2016 & 2017 \\
\hline Materials & 67 & 92 & 108 & 119 & 132 & 143 & 157 & 166 & 166 & 164 & 162 \\
\hline Consumer Goods & 104 & 142 & 154 & 160 & 176 & 192 & 202 & 211 & 215 & 214 & 209 \\
\hline $\begin{array}{l}\text { Consumer } \\
\text { Services }\end{array}$ & 42 & 61 & 73 & 77 & 88 & 94 & 102 & 109 & 110 & 113 & 114 \\
\hline Health Care & 25 & 35 & 38 & 42 & 45 & 47 & 51 & 51 & 50 & 53 & 53 \\
\hline Industrials & 260 & 355 & 406 & 450 & 484 & 504 & 523 & 568 & 575 & 582 & 579 \\
\hline Oil \& Gas & 5 & 6 & 6 & 6 & 7 & 8 & 9 & 10 & 10 & 10 & 10 \\
\hline Technology & 21 & 24 & 28 & 28 & 27 & 27 & 28 & 29 & 29 & 29 & 29 \\
\hline $\begin{array}{l}\text { Telecommun- } \\
\text { ications }\end{array}$ & 2 & 2 & 5 & 5 & 5 & 5 & 5 & 7 & 7 & 7 & 7 \\
\hline Utilities & 31 & 45 & 52 & 59 & 73 & 91 & 95 & 110 & 112 & 112 & 115 \\
\hline Total & $\mathbf{5 5 7}$ & 762 & 870 & 946 & $\mathbf{1 , 0 3 7}$ & 1,111 & 1,172 & 1,261 & 1,274 & 1,284 & 1,278 \\
\hline
\end{tabular}

Number of firms allocated by sector and year respectively. The number of firms by sector increased every year. Firms in the Industrials sector account for the majority (45\% - 48\%) and the number of firms in the Telecommunications industry accounts for less than $1 \%$ in the data set.

\subsection{Analysis Techniques}

With large, complex and observations sample and tabulated for all listed firms in the Vietnamese stock market, the Fixed Effects and Random Effects regression methods are selected.

$$
y_{i t}=\beta_{1} X_{i t 1}+\beta_{2} X_{i t 2}+\mu_{i t}
$$

$\mathrm{i}=1,2, \ldots \mathrm{n}$ and $\mathrm{t}=1,2, . ., \mathrm{t}$

The error of the model is split into two parts: $\mu_{i t}=\vartheta_{i}+$ $\varepsilon_{i t}$ where is the unobserved differences between the objects but does not change over time, $\mathrm{t}$ is the other unobserved elements between objects and change over time.

We used Hausman Test to determine an appropriate estimation method between fixed impact and random impact model of data table. Hausman Test propounded two theories about the correlation among the independent variables of the model which was given in the study (Hausman, 1978) on the basis of inheritance and development from theories in the study (Wu, 1973). Fixed Effects Regression is selected. 
On the basis of identifying the determinants which affected the sustainability of profit in model 1 and special character of the business, the sustainability level was verified through Pers index in model (1.3). This was an important indicator to estimate the sustainability level as well as the volatility of the index in the data table, which brought many statistical and economic significance.

The profit forecast: Used a combination of analysis according to the degree of influence which divided by the quintile of the determinants and changed the time period to assess the predictability of each element in the model (2) and (3). The quintile regression model divided the data into 5 equal parts $(\mathrm{k}=1,2,3$ or 4$)$ and conducted each section independently to see the difference in each percentile, thence assessed the determinants' influence to the specific model. This was the way for investors to forecast the profit easily in the short-term and long-term and evaluated the accuracy of forecasting models in each different level (Furno, 2018).

Additionally, the authors used the model (4) to evaluate the impact of the past profit elements to the future profits through testing fixed and random effect model, tested according to the sustainable impact model. From the results of model (4), the correlation among three determinants: the profit elements, current profit and future profit were more comprehensively identified. In addition, this regression also provided a comparison of the possibility of regression in the past with Pers index in the model (1.3), thence helped investors to get the most effective forecasting tool when making decisions.

\section{Results and Discussion}

\subsection{Estimating Sustainable Earnings for Listed Firms}

The impact of determinants estimation on the profitability of firms through Fixed effects model and Random effects model showed that all determinants affect the fluctuation of the difference of annual profit, in which there are 8 negative impact determinants (coefficient with negative sign) and 2 positive impact determinants (coefficient with positive sign). This showed that the level of fluctuation of marginal profit depends heavily on the value of SUE in the previous year (the coefficient is 1.2355) and the impact level of the determinants which have absolute value less than 1 and range from -0.8347 to 0.1686 . Typically, we can see a lot of factors that have a significant impact on the profit volatility level, such as the correlation between the profit fluctuation and the assets turnover in the same period (-0.8347) and the relationship between income of firms in the last 2 years $(-0.8219)$. This is not appropriate with the results presented in the study of (Chen, 2004) most of the factors have a positive impact and with a large coefficient on the marginal profit fluctuation (see Table 5).

Table 5: Determinants influencing firm's persistence of profit

\begin{tabular}{|c|c|c|c|c|}
\hline & \multicolumn{2}{|c|}{ Fixed-Effects } & \multicolumn{2}{|c|}{ Random-Effects } \\
\hline & $\begin{array}{l}\text { Mean } \\
\text { Coef. }\end{array}$ & t-stat & $\begin{array}{l}\text { Mean } \\
\text { Coef. }\end{array}$ & t-stat \\
\hline $\mathrm{SUE}_{\mathrm{t}-2}$ & 1.2355 & 20.90 & 0.9820 & 18.81 \\
\hline HERF*SUE ${ }_{\mathrm{t}-2}$ & -0.0243 & -0.27 & -0.0673 & -0.83 \\
\hline $\mathrm{CI} * \mathrm{SUE}_{\mathrm{t}-2}$ & -0.4459 & -2.48 & -0.1985 & -1.19 \\
\hline DPM*SUE $E_{t-2}$ & -0.1169 & -3.29 & -0.1881 & -5.89 \\
\hline DATO $* \mathrm{SUE}_{\mathrm{t}-2}$ & -0.8347 & -20.88 & -0.7945 & -22.56 \\
\hline $\mathrm{GA}^{*} \mathrm{SUE}_{\mathrm{t}-2}$ & -0.0003 & -0.04 & -0.0102 & -1.51 \\
\hline $\begin{array}{l}\text { DPMATO } \\
2\end{array}$ & 0.1686 & 4.14 & 0.1027 & 2.77 \\
\hline $\begin{array}{l}\text { DATOGA }_{2} * \mathrm{SUE}_{\mathrm{t}-} \\
\end{array}$ & -0.4471 & -14.34 & -0.6399 & -22.75 \\
\hline $\mathrm{ACCR} * \mathrm{SUE}_{\mathrm{t}-2}$ & 0.0118 & 1.02 & 0.0106 & 0.99 \\
\hline LOSS $* \mathrm{SUE}_{\mathrm{t}-2}$ & -0.8219 & -13.48 & -0.5259 & -10.59 \\
\hline $\mathrm{DECR} * \mathrm{SUE}_{\mathrm{t}-2}$ & -4.0548 & -16.37 & 0.0098 & 0.32 \\
\hline Mean R & 0.1793 & & 0.1687 & \\
\hline Total variables & 7.517 & & 7.517 & \\
\hline
\end{tabular}

Sustainability of corporate profits is measured by Pers index. The trend of profit change is reflected in whether the changeable of marginal profit, the fluctuations in margins are positive or negative, and how they affect investors' choices. Pers results showed that the sustainability of the corporate profits on the Vietnam Stock Exchange was quite diverse and varies widely, from -3.8250 to 2.4368 . The average value of Pers by -0.0850 showed the marginal profit fluctuation was not too large (see Table 6). This result is in contrast to the study of Chen (2004). In order to have a deeper perspective on sustainable measures across the Vietnam Market, the authors estimated Pers index of firms by sectors.

Although the market's Pers index is negative, most industries are positive, except for the health care. Industry includes 579 firms, accounting for $45.3 \%$ of the number of Vietnamese listed firms. Therefore, the industry Pers is 0.3715 which has a strong impact on the index, leading to the negative overall market index.

In contrast to the basic materials industry, the Pers index is 0.4025 . The industry's Perspective is much higher than the market-wide Pers. This result is consistent with previous studies measuring the specific nature of the basic materials industry (Chen, 2004). Consumer goods industry with 209 firms. 
Table 6: Estimate Pers by sectors

\begin{tabular}{|c|c|c|c|c|}
\hline Sectors & Obs & Mean & $\mathbf{n}$ & Max \\
\hline Basic materials & 1,300 & 0.4025 & -9.7910 & 7.2106 \\
\hline Consumer goods & 1,748 & 0.0511 & -12.9768 & 352.3363 \\
\hline Customer service & 862 & -0.0958 & -88.8640 & 18.1120 \\
\hline Health care & 431 & -1.7140 & -250.854 & 12.2616 \\
\hline Industry & 4,633 & -0.3715 & -2.9395 & 22.4686 \\
\hline Oil and Gas & 76 & 0.3890 & -2.0384 & 6.0680 \\
\hline Technology & 268 & 0.1013 & -2.4451 & 8.3959 \\
\hline Telecommunication & 48 & 1.2317 & -7.3439 & 11.3894 \\
\hline Utilities & 756 & 0.2014 & -15.8478 & 77.1564 \\
\hline
\end{tabular}

This day has positive Pers +0.01111 , but quite close to the market value of Pers, expressing a high level of reliability, or in other words, consumer goods has a quite sustainable profitability.

In addition, a particular industry of Vietnam's market is oil and gas industry. The industry's Pers index is +0.3890 . This value is quite large, reflecting the high level of profitability of the whole industry compared to the entire Vietnam market. It can be seen that competitive determinants and advantages of business conditions also create a certain sustainability of profits of businesses.

\subsection{Predict Future Profits}

Model (2) is selected regressively to directly assess the future self-predictability of profit margins and the ability to predict future profits based on the sustainable profitability index calculated from the above, this is the simplest model but can also contain many defects and give inaccurate results (see Table 7).

Table 7: Regression model results (2)

\begin{tabular}{|c|c|c|c|c|c|}
\hline & $k=1$ & $k=2$ & $k=3$ & $k=4$ & $k=5$ \\
\hline \multicolumn{6}{|l|}{ Model (2.1) } \\
\hline $\mathrm{a}_{\mathrm{k}}$ & 11.6656 & 9.2327 & 11.9370 & 8.7115 & 10.6572 \\
\hline t-stats & 5.20 & 3.78 & 3.14 & 2.75 & 2.95 \\
\hline$b_{k}$ & -0.1007 & -0.0191 & -0.1851 & 0.0596 & 0.0292 \\
\hline t-stats & -9.22 & -1.49 & -9.11 & 2.46 & 1.05 \\
\hline Mean Adj-R & 0.3100 & 0.1046 & 0.0815 & 0.0839 & 0.0825 \\
\hline \multicolumn{6}{|l|}{ Model (2.1) } \\
\hline$a_{k}$ & 14.4126 & 6.8958 & 11.8774 & 5.2741 & 6.9957 \\
\hline t-stats & 6.42 & 2.81 & 3.15 & 3.17 & 1.94 \\
\hline$b_{k}$ & -0.0582 & -0.0893 & -0.1809 & 0.0171 & -0.0011 \\
\hline t-stats & -5.20 & -6.32 & -8.52 & 0.69 & -0.04 \\
\hline $\mathrm{c}_{\mathrm{k}}$ & -3.3151 & -0.7189 & 1.2004 & 1.4570 & 1.2306 \\
\hline t-stats & -4.15 & -0.17 & 0.25 & 0.27 & 0.20 \\
\hline$d_{k}$ & 0.3053 & -0.2797 & -0.0068 & -0.4757 & -0.5328 \\
\hline t-stats & 15.54 & -11.82 & -1.05 & 8.61 & 1.94 \\
\hline Mean Adj-R & 0.4910 & 0.0633 & 0.0817 & 0.0056 & 0.0708 \\
\hline Total variables & 8,761 & 7,435 & 6,199 & 5,093 & 4,042 \\
\hline
\end{tabular}

The results of the model (2) as an origin point to evaluate the regression results of the model (3). The results are significant in predicting the profitability of businesses with the base year to year forecast of 1 to 5 years, respectively. The values of autocorrelation coefficients $b_{k}(-0.1007$, $0.0191,-0.01851,0.0596,0.0292$ with $\mathrm{k}$ equals $1,2,3,4,5$ respectively) show the different from Chen (2014). The autocorrelation coefficient $b_{1}=-0.1007$, this value is close to the average of Pers variable calculated in the model (1).
This suggests that Pers index reflects quite accurately the firm's profitability in the short-term. The sign (-) of the correlation coefficients also shows the concern about future profitability changes when all indications of future decline. This result is supported by previous studies (e.g., Chen, 2004; Dichev \& Tang, 2009; Frankel \& Litov, 2008).

Results table Model (3) show that the result of regressing $\mathrm{SUE}_{\mathrm{t}+\mathrm{k}}$ variable according to the variables $\mathrm{SUE}_{\mathrm{t}}, \mathrm{Pers}_{\mathrm{t}}$ and the product of the above two variables to evaluate the 
ability of Pers $\mathrm{t}_{\mathrm{t}}$ variable in assessing the sustainability of profit. The coefficient $d_{k}$ is expected to be 1 because then Pers $_{t}$ - the variable formed from the SUE self-regression model - will fully reflect the change in SUE's selfregression structure. At the same time, the index $b_{k}$ coefficient of the Pers variable - is expected to be 0 . From the model results we see that with $\mathrm{k}=1$, the 2 coefficients $b_{k}$ and $d_{k}$ are all near the expected threshold $\left(b_{1}=-0.0582\right.$ and $\mathrm{d}_{1}=0.3053$ ). With $\mathrm{k}=2.3 \mathrm{~b}_{\mathrm{k}}$ falling to a negative level $(-0.0893,-0.1809)$ this indicates a negative sign when both the sustainability of the profit lies at a negative level and may have negative impacts on firm with $\mathrm{k}=4.5, \mathrm{~b}_{\mathrm{k}}$ gives a better value, this is a very positive thing to show predictability and meet the expectations of the model. The value of $d_{k}$ at $k=2,3,4,5$ all returns to the negative level, which is the negative value that is misleading for future earnings forecast of the business.

\subsection{Determine the Relationship between the Volatility of Profit and the Ability to Forecast Profits}

Profit forecast by quintile: Model (2) is a model that evaluates the self-predictability of profit based on the profit of the previous period. The results of the quintile regression are as follows (see Table 8):

Table 8: Results for the earnings persistence regression

\begin{tabular}{|c|c|c|c|c|}
\hline \multirow{2}{*}{ Quintile } & \multicolumn{4}{|c|}{ 及 } \\
\cline { 2 - 5 } & Earnings volatility & $\begin{array}{c}\text { Absolute amount of } \\
\text { accruals }\end{array}$ & Earnings level & Cash flow volatility \\
\hline Quintile 1 & 0.8053 & 06646 & 0.7216 & 0.6199 \\
\hline Quintile 2 & 0.8433 & 0.6646 & 0.7140 & 0.6674 \\
\hline Quintile 3 & 0.8128 & 0.6809 & 0.8241 & 0.8115 \\
\hline Quintile 4 & 0.6790 & 0.6814 & 0.8316 & 0.8733 \\
\hline Quintile 5 & 0.6536 & 0.7769 & & 0.8313 \\
\hline Difference & 0.1517 & -0.1123 & 0.7509 & -0.2114 \\
\hline
\end{tabular}

The result of the regression $\beta$ across the whole market is 0.8241 , indicating a negative relationship between the hypothesis of profit volatility and the sustainability of firm profitability. The above results also show that the level of volatility of profits and profits positively affects the sustainability of profits. On the contrary, the accrued profit and the movement of operating cash flow negatively impact the sustainability of these businesses. Also from this result shows that the percentile 1 to the 5-indicator unit of profitability according to the fluctuation of profit and the fluctuation of cash flow of business operations. This result also confirms the contradictory law between maximizing profitability and increasing the solvency of businesses in Ross corporate finance management (2016). Meanwhile, the prediction results based on the units based on profitability are presented in Table 4.16, showing a sustainable index of volatility fluctuations between units and adjusted R-square from 0.2698 in percentile 1 down to 0.4083 in percentile 4 and decrease to 0.3663 in percentile 5 . The significance of the independent variable is larger than the running model according to the quintile of the accrued profit. This result is similar to the test result of Dichev and Tang (2009) when showing the ability to predict profitability based on profit level and adjusted R2 to the highest level in the average units (e.g., Dichev \& Tang, 2009; Frankel \& Litov, 2008).

From the forecast of sustainable profits according to the quintile, long-term profit forecasts help to make judgments about the stability of profitability of businesses. Forecasting profits in the long term (5 years) is as follows (see Table 9):

Table 9: Model regression results table (3)

\begin{tabular}{|c|c|c|}
\hline Items & $\boldsymbol{\beta}$ & Adj-R \\
\hline Market overall & 2.6903 & 0.3938 \\
\hline Max fluctuations & 2.2152 & 0.1221 \\
\hline Min fluctuations & 3.0434 & 0.3038 \\
\hline
\end{tabular}

From the regression results, the indicators reflect quite accurately and in accordance with the theory of economics and statistics. Businesses with large profit fluctuations have a lower level of sustainable profitability than many businesses with stable profits. For the whole market, this index is quite high, close to the group of businesses with the most stable profit and the significance level is also very high (0.3938), which shows that despite the overall profit index is negative. But in the long term, it is still possible to make positive comments and expectations for the profit of the market.

Test the role of components of past sustainable profits in predicting future profits:

From the regression results, the $\mathrm{P}$-value of all variables is less than 0.05 , indicating significant variables affecting the dependent variable NI. The statistic value $t$ must be higher 
than 1.96 , and the variables will satisfy this. Therefore, the variables have a significant influence on the dependent variable, the higher the t-statistic value shows, the greater the correlation between that variable and the dependent variable (NI). Realizing that $\mathrm{t} \_\mathrm{FCF}=34.1$ is higher than $\mathrm{t}$ $(\mathrm{CACC})=22.56$ and $\mathrm{t} \mathrm{NCACC}=5.61$, so the effect of free cash flow is higher than short-term accrued profit from business activities in a suitable future profit forecast with the Examining the Earnings Persistence and Its Components results in Explaining the Future Profitability (Moienadin \& Tabatabaenasab, 2014) (see Table 10).

Table 10: Regression results model (4)

\begin{tabular}{|c|c|c|c|}
\hline Variables & $\begin{array}{c}\text { Mean } \\
\text { Coef. }\end{array}$ & Stt. Err. & t-stat \\
\hline CACC & 0.0842 & 0.0037 & 22.56 \\
\hline FCF & 0.1748 & 0.0051 & 34.10 \\
\hline NCACC & 0.0269 & 0.0048 & 5.61 \\
\hline Cons & 77.1401 & 2.2542 & 34.22 \\
\hline $\begin{array}{c}\text { Adj-R: } \\
0.2906\end{array}$ & & & \\
\hline Obs: & & & \\
\hline 0,159 & & & \\
\hline
\end{tabular}

\section{Conclusion}

Through the analysis of the determinants influencing sustainable profitability, we examined the impact of these determinants on the sustainability of the firms' profits, thereby giving the formula of calculation. This sustainable indicator and the method of predicting future profits for firms.

The study provides a measure of the Pers index - an indicator of profitability (e.g., Chen, 2004; Narayanamoorthy, 2006; Frankel \& Litov, 2009; Rangan \& Sloan, 1998; Penman \& Zhang, 2004). After verification, the result of Vietnam market Perspectives index is -0.0850 , showing that the profits of firms in Vietnam market are not sustainable. This result shows the differentiation of firms in the industry, with large gaps and uneven changes. In some sectors, large-scale firms have stable profits and growth rates. On the contrary, there are small-scale businesses and production and business capabilities, business activities are not focused, profits and profit growth are low, even at a loss. Accordingly, these businesses face an imbalance in profit, affecting the entire industry and the whole market.

The results also show Herfindahl index on the concentration of the industry (Lev, 1983; Chen, 2004; Gregory et al., 2016; Frankel \& Litov, 2009), correlation between asset turnover and changes in income with asset growth during the period (Chen, 2004; Penman \& Zhang, 2004), correlation between accrued profits and revenue (Chen, 2004; Narayanamoorthy, 2006; Frankel \& Litov, 2009; Rangan \& Sloan, 1998) have a negative impact on previous studies at some developed market in the world. This is a particular factor of the market. In Vietnam's growing market, businesses have not really positioned their business and mainly classified relative industries based on the weight of revenue in the total revenue of the business. Therefore, create a certain dispersion on the concentration of careers.

In addition, it can be seen that the number of firms in the industry is not divided according to the rules. In the same industry, there are very large firms with large scale and concentration, but there are also small-scale firms with low concentration. In the industry, this is the industry with the proportion of firms accounting for half of the total number of firms operating in Vietnam and there is an increasing prospect. However, the ability of these firms to operate is quite large. Some firms are very developed with a large market share in the industry, Herfindahl index is high with high concentration of industries and vice versa, some firms are small, firm activities are not concentrated and market share in the industry only accounts for a small, even very small share. This is also one of the reasons for the profitability of this industry to reach very low.

\section{References $_{\text {s }}$}

Abarbanell, J. S., \& Bushee, B. J. (1997). Fundamental Analysis, Future Earnings, and Stock Prices. Journal of Accounting Research, 35(1), 1-24.

Al-Momani, M. A., \& Almomani, T. M. (2018). The Impact efficiency of using assets to enhance earnings quality in the Jordanian Industrial Companies listed in the Amman Stock Exchange: An Empirical Study. International Journal of Business and Management, 2(2), 40-46.

Amir, E., Einhorn, E., \& Kama, I. (2012). Extracting Sustainable Earnings from Profit Margins. European Accounting Review, 22(4), 685-718.

Ball, R., \& Watts, R. (1972). Some Time Series Properties of Accounting Income. Journal of Finance, 27(3), 663-681.

Ball, R., Gerakos, J., Linnainmaa, J., \& Nikolavea, V. (2016). Accruals, cash flows, and operating profitability in the cross section of stock returns. Journal of Financial Economics, 121, 28-45.

Barth, M. E., \& Hutton, A. P. (2004). Analyst Earnings Forecast Revisions and the Pricing of Accruals. Review of Accounting Studies, 9(1), 59-96.

Basu, S. (1977). Investment Performance of Common Stocks in Relation to their Price-Earnings Ratios: A test of the efficient market hypothesis. The Journal of Finance, 32(3), 663-682.

Beaver, W., \& Kettler, P. (1970). The Association Between Market Determined and Accounting Determined Risk Measures. The Accounting Review, 45, 654-681. 
Beaver, W., \& Morse, D. (1978). What Determines Price-Earnings Ratios? Financial Analysts Journal, 34(4), 65-76.

Beaver, W., \& Morse, D. (1978). What Determines Price-Earnings Ratios?. Financial Analysts Journal, 28, 65-76.

Bhattacharya, N., Desai, H., \& Venkataraman, K. (2012). Does Earnings Quality Affect Information Asymmetry: Evidence from Trading Costs. Contemporary Accounting Research, 482516.

Brooks, L. D., \& Buckmaster, D. A. (1976). Further Evidence on the Time Series Properties of Accounting Income. American Finance Association, 31, 1359-1373.

Brownlee, M., Ferris, K., \& Haskins, M. (1990). Financial Accounting and Reporting. Homewood, CA: Irwin.

Chan, L. K. C., Lakonishok, J., \& Sougiannis, T. (2001). The Stock Market Valuation of Research and Development Expenditures. The Journal of Finance, 56(6), 2431-2456

Chen, C. (2004). Earnings Persistence and Stock Price Underand Overreaction. Madison, WI: Documento de trabajo University of Wisconsin-Madison.

Damodaran, A. (1999). Investment Valuation: Tools and Techniques for Determining the Value of any Asset. New York, NY: John Wiley \& Sons.

Dang, M. H., \& Tran, M. D. (2019). Relationship between Accrual Anomaly and Stock Return: The Case of Vietnam. Journal of Asian Finance, Economics and Business, 6(4), 19-26. https://doi.org/10.13106/jafeb.2019.vol6.no4.19

Dao, T. T. B., \& Lai, H. P. (2018). A Study on Optimal Capital Structure of Vietnamese Real Estate Listed Firms. Journal of Economics and Development, 20(3), 45-70.

Darjezi, I. Z. J. (2016)The role of accrual estimation errors to determine accrual and earnings quality. International Journal of Accounting and Information Management, 24(2), 98-115.

Das, S., \& Lev, B. (1994). Nonlinearity in the Returns-Earnings Relation: Tests of Alternative Specificationsand Explanations. Contemporary Accounting Research, 11(1), 353-379.

Dechow, P., \& Ross, S. (2005). The persistence of earnings and cash flows and the role of special items, implications for the accrual anomaly (Working Paper).

Dechow, P. M., \& Dichev, I. D. (2001). The quality of accruals and earnings: The role of accrual estimation errors. The Accounting Review, 77, 35-59.

Dechow, P. M., Ge, W., \& Schrand, C. M. (2009). Understanding Earnings Quality: A Review of the Proxies, Their Determinants and Their Consequences. Journal of Accounting and Economics, 50, 344-401.

Dechow, P. M., \& Ge, W. (2006). The persistence of Earnings and Cash flows and the role of special items: Implication for the accrual anomaly. Review of Accounting Studies, 11(2), 253296.

Dechow, P. M., \& Schrand, C. M. (2004). Earnings Quality. Charlottesville, VA: The Research Foundation of CFA Institute.

Dechow, P. M., Richardson, S. A., \& Sloan, R. G. (2008). The Persistence and Pricing of the Cash Component of Earnings. Journal of Accounting Research, 46(3), 537-566.

Dichev, I. D., \& Tang, V. W. (2009). Earnings volatility and earnings predictability. Journal of Accounting and Economics, 47(1-2), https://doi.org/10.1016/j.jacceco.2008.09.005

Fairfield, P. M., \& Yohn, T. L. (2001). Using Asset Turnover and
Profit Margin to Forecast Changes in Profitability. Review of Accounting Studies, 6(4), 371-385.

Frankel, R., \& Litov, L. (2009). Earnings Persistence. Journal of Accounting and Economics, 47(1-2),182-190.

Freeman, R. N., \& Tse, S. (1989). The Multiperiod Information Content of Accounting Earnings: Confirmations and Contradictions of Previous Earnings Reports. Journal of Accounting Research, 27, 49-79.

Freeman, R. N., \& Tse., S. Y. (1992). A Nonlinear Model of Security Price Responses to Unexpected Earnings. Journal of Accounting Research, 30(2), 185-209. DOI: 10.2307/2491123

Furno, M., \& Vistocco, D. (2018). Quantile Regression: Estimation and Simulation (pp. 50-62). New York, NY: John Wiley \& Sons.

Graham, B., \& Dodd, D. L. (1951). Security Analysis: Principals and Technique (1st ed.). New York, NY: McGraw-Hill Book Company, Inc.

Gregory, A., Whittaker, J., \& Yan, X. (2016). Corporate social performance, competitive advantage, earnings persistence and firm value. Journal of Business Finance \& Accounting, 43(1), 3-30.

Haskins, M., Ferris, K., Sack, R., \& Allen, B. (1993). Financial Accounting and Reporting. Homewood, CA: Irwin.

Hausman, J. A. (1978). Specification Tests in Econometrics. Econometrica, 46(6), 1251-1271.

Hogan, R.S. (2013). The effect on earnings persistence and the market's reaction to the alignment of employee and customer relations with competitive strategy. Baton Rouge, LA: Louisiana State University.

Hutton, A. P., Miller, G. S., \& Skinner, D. J. (2003) The Role of Supplementary Statements with Management Earnings Forecasts. Journal of Accounting Research, 41(5), 867-890.

Jackson, A. B., Plumlee, M. A., \& Rountree, B. R. (2018). Decomposing the market, industry, and firm components of profitability: Implications for forecasts of profitability. Review of Accounting Studies, 23, 1071-1095.

Johnson, M. F. (1999). Business Cycles and the Relation between Security Returns and Earnings. Review of Accounting Studies, 4, 93-117.

Kieso, D. E., \& Weygandt, J. J. (1995). Intermediate Accounting (8th ed.). New York, NY: John Wiley \& Sons.

Kocamis, T. U., \& Gungor, A. (2016). An Analysis of Relationship Between Sustainable Tourism and Sustainable Profitability In Tourism Sector, The Case of Turkey. International Journal Advances in Social Science and Humanities, 4(5), 1-9.

Kormendi, R., \& Lipe, R. (1994). Mean Reversion in Annual Earnings and Its Implications for Security Valuation. Review of Quantitative Finance and Accounting, 4, 27-46.

Lau, W. T., \& Mahat, F. B. (2019). Robustness of Cash Flow Value: Investment in ASEAN. Journal of Asian Finance, Economics and Business, 6(2), 247-255. https://doi.org/10.13106/jafeb.2019.vol6.no2.247

Le, K. N., \& Truong, D. K. (2019). Trade credit use by shrimp farmers in $\mathrm{Ca} \mathrm{Mau}$ province. Journal of Economics and Development, 21(2), 270-284.

Lev, B., \& Thiagarajan, S.R. (1993). Fundamental Information Analysis. Journal of Accounting Research, 31(2), 190-215.

Lev, B. (1983). Some economic determinants of time-series properties of earnings. Journal of Accounting and Economics, 
$5,31-48$.

Li, F. (2005). Annual Report Readability, Current Earnings, and Earnings Persistence. Journal of Accounting and economics, 45(2-3), 221-247.

Lyimo, G. D., \& Jain, G. (2014). Predictability Persistence of Earnings and stock price synchronicity evidence from Indian stock market. International Journal of Economics, Commerce and Management, 2(6), 1-16.

Moienadin, M., \& Tabatabaenasab, Z. (2014). Examining the Earnings Persistence and Its Components in Explaining the Future Profitability. Interdisciplinary Journal of Contemporary Research in Business, 5(10), 104-117.

Muhammad, H., Rehman, A.U., \& Waqas, M. (2016). The Relationship between Working Capital Management and Profitability: A Case Study of Tobacco Industry of Pakistan. Journal of Asian Finance, Economics and Business, 3(2), 1320. https://doi.org/10.13106/jafeb.2016.vol3.no2.13.

Narayanamoorthy, G. (2006). Conservatism and Cross-Sectional Variation in the Post-Earnings Announcement Drift. Journal of Accounting Research, 44(4), 763-789.

Nguyen, T. H., Nguyen, M. H., \& Nguyen, T. T. L. (2014). Impact of accrual accountings on sustainability of profits of listed firms. Journal of Banking Technology, 23, 15-22.

Nguyen, T. H. H., Nguyen, T. D., \& Pham, H. A. (2019). Three effects of stock repurchase on rival firms in Vietnam. Journal of Economics and Development, 21(1), 57-70.

Nguyen, T. N. L., \& Nguyen, V. C. (2020). The Determinants of Profitability in Listed Enterprises: A Study from Vietnamese Stock Exchange. Journal of Asian Finance, Economics and Business, 7(1), 47-58. https://doi.org/10.13106/jafeb.2020.vol7.no1.47

Penman, S. H., \& Zhang, X. J. (2004). Modeling Sustainable Earnings and $P / E$ Ratios Using Financial Statement Information. New York, NY: Columbia University.

Rangan, S., \& Sloan, R. G. (1998). Implications of the Integral Approach to Quarterly Reporting for the Post-EarningsAnnouncement Drift. The Accounting Review, 73(3), 353-371.

Richardson, S. A., Sloan, R. G., Soliman, M. T., Tunaa, I. (2005). Accrual reliability,earnings persistence and stock prices. Journal of Accounting and Economics, 39(3), 437-485.

Schröder, D., \& Yim, A. (2017). Industry Effects in Firm and Segment Profitability Forecasting. Contemporary Accounting Research, 35(4), 2106-2130.

Sloan, R. G. (1996). Do Stock Prices Fully Reflect Information in Accruals and Cash. The Accounting Review, 71(3), 289-315.

Wu, D. M. (1973). Alternative Tests of Independence between Stochastic Regressors and Disturbances. Econometrica, 41(4), 733-750.

Xie, H. (2005). The Mispricing of Abnormal Accruals. The Accounting Review, 76, 357-373. 